\title{
ASSESSMENT OF HEAVY METALS IN FISHES (Ictalurus Punctatus) FROM RIVER NUN WITHIN TOMBIA AND POLAKU AXIS, BAYELSA STATE
}

\author{
Orodu V.E ${ }^{1}$, Onwukwe Ikechukwu Godfirst ${ }^{2}$ \\ ${ }^{1}$ Department of Chemical Sciences, Niger Delta University, Wilberforce Island, P.M.B 017, \\ Yenegoa, Nigeria \\ ${ }^{2}$ Department of Chemical Science, Niger Delta University, Wilberforce Island P.M.B 017, Yenegoa, \\ Nigeria
}

Keyword: Ictalurus Punctatus; Heavy Metals; WHO

Abstract: The concentration of the following heavy metals ( $\mathrm{Fe}, \mathrm{Pb}, \mathrm{Cd}, \mathrm{Cu}, \mathrm{\&} \mathrm{Cr}$ ) in fishes (Ictalurus Punctatus) from River Nun within the Tombia and Polaku axis located in Bayelsa State Nigeria was studied. The gills, Kidney, liver, bones and flesh of the fishes after oven dried for 72 hours were ground together into powder. One gram of the ground sample was weighed and digested using aqua regia in the ratio of 3:1 $\left(\mathrm{HNO}_{3}\right.$ and $\left.\mathrm{H}_{2} \mathrm{SO}_{4}\right)$. The sample was then filtered and run in an AAS. The following results were observed and presented in mean \pm SEM. For Tombia Fish; Fe recorded a concentration of $1.910 \pm$ $0.001 \mathrm{mg} / \mathrm{kg}$, lead recorded $0.707 \pm 0.001 \mathrm{mg} / \mathrm{kg}$, Chromium $=0.451 \pm 0.001 \mathrm{mg} / \mathrm{kg}$, Copper $=0.246 \pm 0.001 \mathrm{mg} / \mathrm{kg}$, and Cadmium $=0.070 \pm 0.001 \mathrm{mg} / \mathrm{kg}$. While for Polaku Fish, $\mathrm{Fe}=0.128 \pm 0.001 \mathrm{mg} / \mathrm{kg}, \mathrm{Pb}=0.004 \pm 0.001 \mathrm{mg} / \mathrm{kg}, \mathrm{Cu}=0.002 \pm 0.001 \mathrm{mg} / \mathrm{kg}, \mathrm{Cr}$ and $\mathrm{Cd}$ were below detection limit. According to the maximum permissible limits stipulated by World Health Organization (WHO), the two fishes from River Nun within the axis of Polaku and Tombia Community are within the range and fit for consumption by humans. But in comparing the two fishes within these two communities (Tombia and Polaku), there is an increase in lead and cadmium ( $\mathrm{Pb}$ and $\mathrm{Cd}$ ) for Tombia compared to Polaku which might be as a result of the domestic activities carried out at the bank of Tombia river.

\section{Introduction}

Fish products are widely consumed in many parts of the world because it has high protein content, low saturated fatty acids, calcium, phosphorus, iron, and trace elements such as copper as well as a fair proportion of the group B vitamins to support good health. Fish accumulate toxic chemicals 
such as heavy metals directly from water and diet, and contaminant residues may ultimately reach concentrations hundreds or thousands of times above those measured in water, sediment and food (Goodwin et al.,2003; Labonneet al.,2001; Osman et al.,2007).

Fish products now account for 30\% of the human protein supply in Asia, 20\% in Africa, and $15 \%$ in Latin America and the Caribbean. Because they are neutrally buoyant, most fishes have less need for a supporting skeleton, and consequently have a higher ratio of muscle to bone than land animals. This characteristic as well as having high levels of protein, essential fatty acids, minerals and vitamins makes them a very valuable and healthy alternative to other meats (Mozaffarian and Eric, 2006).

Fish accumulate toxic chemicals such as heavy metals directly from water and diet, and contaminant residues may ultimately reach concentrations hundreds or thousands of times above those measured in the water, sediment and food. According to Atuanya et al., (2012), the concentration of heavy metals varies with variation in fish species. Also, the concentrations of these elements in the fish could be related primarily to their feeding habit (Farkaset. al., 2003). Cadmium (Cd) is one of the principal heavy metals responsible for causing kidney damage, renal disorder, high blood pressure, bone fracture and destruction of red blood Cells. Human beings have reported to have nausea and vomiting at a level of $15 \mathrm{mg} / \mathrm{L}$ of cadmium (Nkpaa et al., 2013).

Lead $(\mathrm{Pb})$ is one of the most dangerous pollutants in our environment which accumulates in the body due to its low rate of elimination. Lead enters aquatic systems from urban, mining and agricultural runoff, atmospheric precipitation, plating processes, and gasoline containing lead that leaks from fishery boats and a variety of natural sources. $\mathrm{Pb}$ is known to induce renal tumours, reduce cognitive development, and increase blood pressure and in adults. Other symptoms of $\mathrm{Pb}$ toxicity include gastrointestinal disorders and some liver impairment (Strömgren, T. 1998).

On the other hand, heavy metal pollution has turned into a major problem in the ecosystem, it is extending to every part of the world, because it cannot easily be degradable and also it affects the aquatic organisms due to their toxic effects. For the assessment of the level of metal pollution, fish and water sample can be considered as major source in the aquatic environment. The bioaccumulation of heavy metals in the fish samples may be due to the industrial, domestic and agricultural effluents thrust in near water bodies.

There are essential metals and non- essential metals which are toxic to aquatic organisms such as fish. The essential metals are copper, iron, zinc, manganese, while mercury, lead and cadmium are highly toxic metals. Because of high consumption of fish, the heavy metals from the fish sample will penetrate in human body; if it is present at high concentration they will cause many adverse and toxic effects. So the analysis of heavy metal concentration should be very important in commercial and edible fish and water sample to evaluate the various disturbances or serious diseases for human health. Water, temperature, water velocity and clarity, alkalinity and accessible habitation are the most important factors which affect the fishes from one area to another area. Therefore, this study was undertaken to make available information on the proximate values and the current level of heavy metal contamination of fishes in river nun within the viscinity of Tombia and Polaku Community.

\section{Materials and Methods}

\subsection{Study Area}

The sampling areas for this study are indicated in the Figures below. Polaku Community is found in the region of Bayelsa located in Nigeria, $468 \mathrm{Km}$ south of Abuja, the country's capital. Its geographical coordinates are 5.030287N, 6.281078E.Polaku's Climate is classified as tropical. 
There is significant rainfall in most months of the year. The short dry season has little effect on the overall climate. The Koppen-Geiger climate classification is Am. The average annual temperature is $26.7^{\circ} \mathrm{C}$ in Polaku. In a year, the average rainfall is $2820 \mathrm{~mm}$. precipitation is the lowest in January, with an average of $37 \mathrm{~mm}$. with an average of $468 \mathrm{~mm}$; the most precipitation falls in September. The driest month is January with $37 \mathrm{~mm}$ of rainfall. With an average of $468 \mathrm{~mm}$, the most precipitation falls in September.

Tombia is also situated in Bayelsa State, Nigeria and its geographical coordinates are; 5.001998N, 6.265784E. It has almost the same climatic features as Polaku. It has a tropical climate with significant rainfall in most months of the year. The average annual temperature is $26.5^{\circ} \mathrm{C}$ in Tombia and average annual rainfall is $2601 \mathrm{~mm}$.

\subsection{Collection of samples}

The Fishes were collected from Polaku and Tombia Community respectively on the $26^{\text {th }}$ of January 2018 around 7am in the morning. They were transported to the Department of Chemical Sciences, Niger Delta University. These fishes were dried in the oven for 72 hours before digestion.

\subsection{Names of the fish}

The native name of the fish is "Ikpoki". The common name is "Cat Fish" while the zoological name is "IctalurusPunctatus"
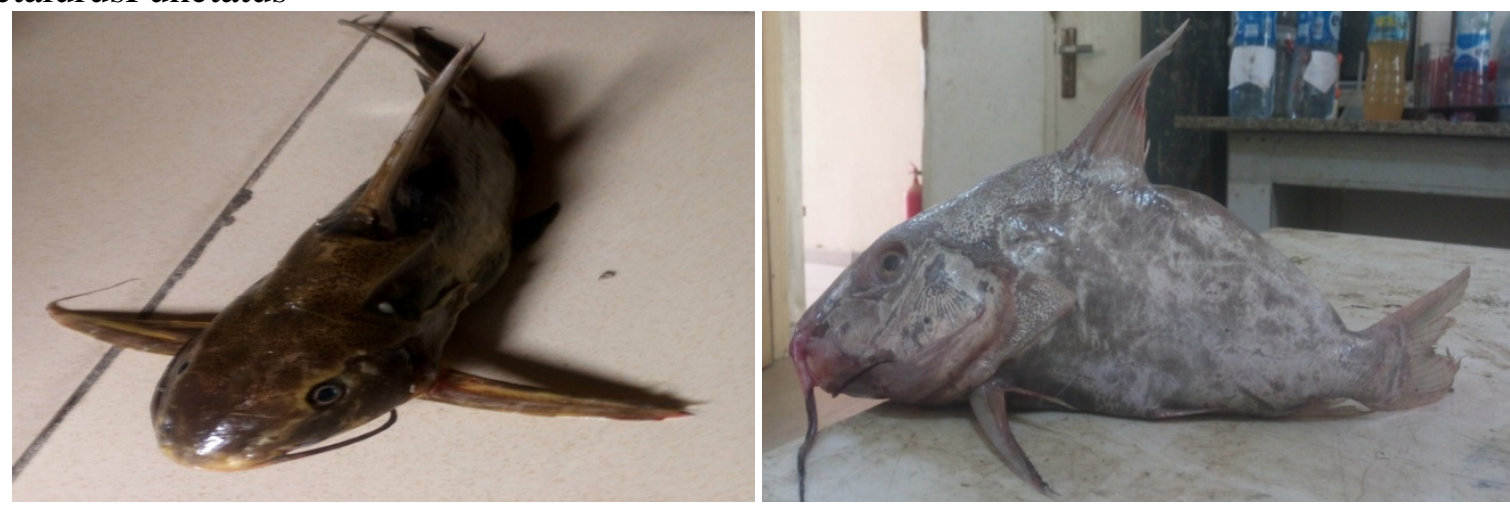

Figure 1: Tombia and Polaku fish (IctalurusPunctatus) from left
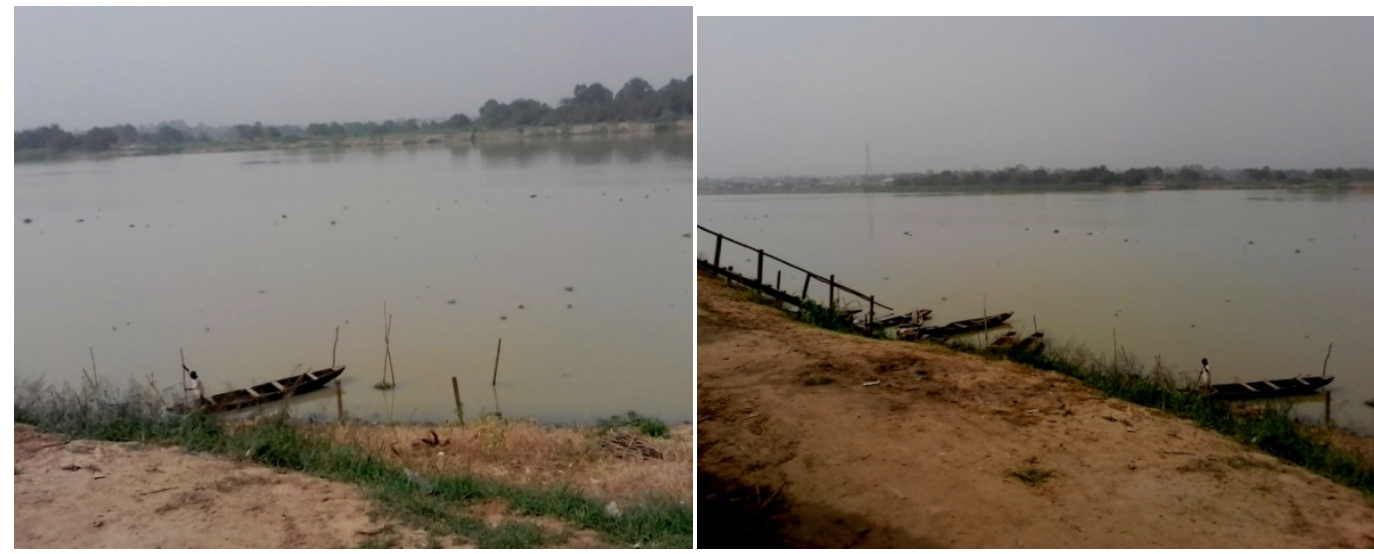

Figure 2: Tombia and Polaku River from left 


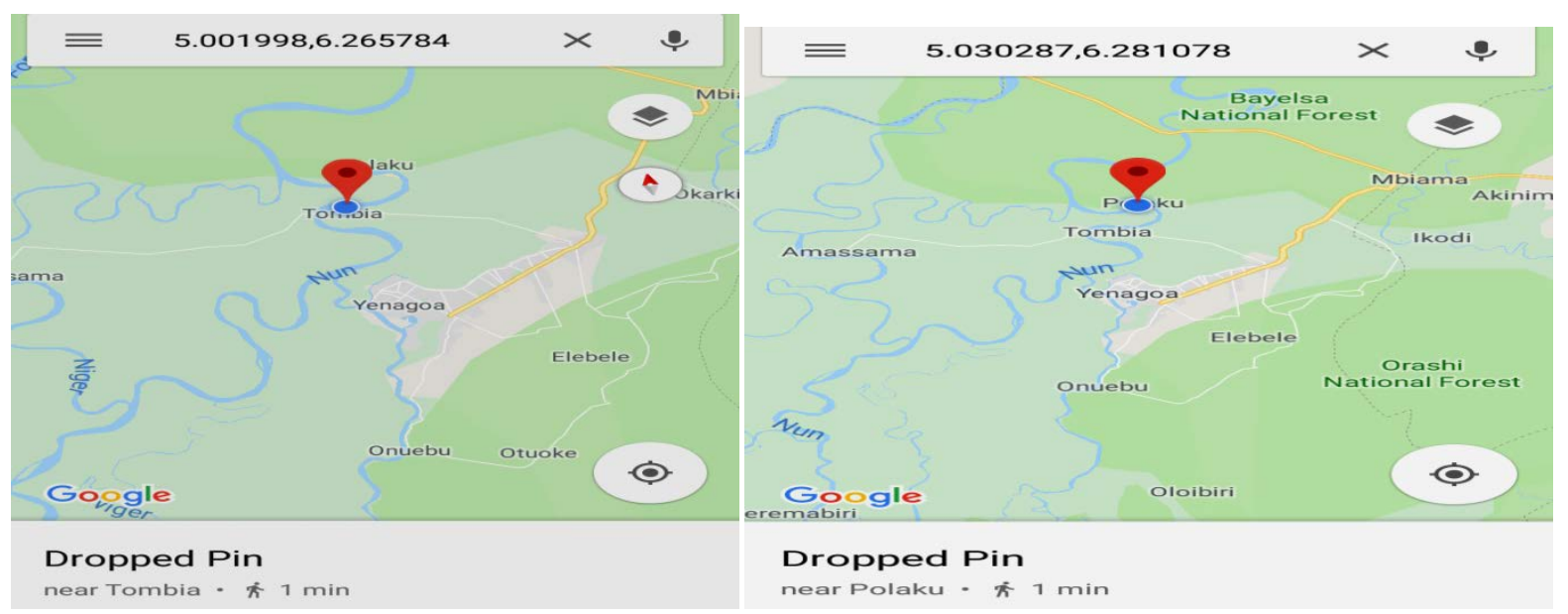

Figure 3: Map Showing the sample location; from left Tombia and Polaku

\subsection{Community}

Heavy Metals to be determined includes; Chromium (Cr), Lead (Pb), Cadmium (Cd), Iron (Fe), and Copper $(\mathrm{Cu})$.

\subsection{Materials and Instruments}

They include;Sample (Fish from Polaku and Tombia River), Plastic Container ,Oven, Mortar, Pestle, Spatula, Weighing Balance, Digestion Flask, Digestion Block, Hot Plate, Volumetric Flask, Plastic Bottles, Whatman filter paper, Timer, Atomic Absorption Spectrophotometer (GBC Avanta PM A6600 AAS).

Reagents used are concentrated nitric acid $\left(\mathrm{HNO}_{3}\right)$ and Sulphuric acid $\left(\mathrm{H}_{2} \mathrm{SO}_{4}\right)$

\subsection{Sample preparation}

Fish samples were taken to the laboratory on that day itself. The fish scales were removed where applicable and washed with running tap water to remove sticky substances. The whole body of the different fish, were then separately oven dried at temperature of $70^{\circ} \mathrm{C}$ for 72 hours.

After drying, portion of the gills, liver, kidney, bones and flesh were mixed together for mastication. These portions were ground thoroughly after which about 1gram of the ground sample was digested with 20ml aqua regia (mixture of nitric acid and sulphuric acid) in the ratio of 3:1 in a 100ml digestion flask and placed on the digestion block in the fume cupboard. This was heated until a clear solution was obtained.

The digested sample was then diluted with $20 \mathrm{ml}$ of distilled water and filtered with whatman filter paper; the filtrate was then taken for AAS (Atomic Absorption Spectroscopy) analysis.

\section{Results and Discussion}

After the sample was analyzed in an AAS (Atomic Absorption Spectrophotometer), the following results were obtained and represented in the table below; 
Table 1: Triplicate Values of Heavy Metals Concentration (mg/kg) for fish within the viscinty of Tombia (punctatusIctalurus)

\begin{tabular}{|l|c|c|c|}
\hline Heavy Metals & \multicolumn{3}{|c|}{ Concentrations (mg/kg) and their triplicate values } \\
\hline & First & Second & Third \\
\hline Copper $(\mathrm{Cu})$ & 0.247 & 0.244 & 0.246 \\
\hline Chromium $(\mathrm{Cr})$ & 0.450 & 0.452 & 0.450 \\
\hline Iron $(\mathrm{Fe})$ & 1.912 & 1.908 & 1.910 \\
\hline Lead $(\mathrm{Pb})$ & 0.709 & 0.706 & 0.706 \\
\hline Cadmium $(\mathrm{Cd})$ & 0.072 & 0.068 & 0.071 \\
\hline
\end{tabular}

\subsection{Discussion}

From the above data, the mean, mean deviation, variance, standard deviation and standard error were derived and the following mean concentration values were calculated: Thus; results are presented as means \pm SEM, and the mean concentration values for Tombia Fish is as follows.

Table 2: Mean Concentration Values of Fish within the viscinity of Tombia (punctatusIctalurus)

\begin{tabular}{|l|c|}
\hline Heavy Metals & Mean Concentration Values (mg/kg) \\
\hline Copper $(\mathrm{Cu})$ & $0.246 \pm 0.001$ \\
\hline Chromium $(\mathrm{Cr})$ & $0.451 \pm 0.001$ \\
\hline Iron $(\mathrm{Fe})$ & $1.910 \pm 0.001$ \\
\hline Lead $(\mathrm{Pb})$ & $0.707 \pm 0.001$ \\
\hline Cadmium & $0.070 \pm 0.001$ \\
\hline
\end{tabular}

From the above data, it was observed that Iron $(\mathrm{Fe})$ has the highest mean concentration in the fish sample with a value of $1.910 \pm 0.001$. Iron $(\mathrm{Fe})$ is an essential element in human diet; it forms part of haemoglobin, which allows oxygen to be carried from the lungs to the tissues. Severe Iron (Fe) deficiency causes anaemia in humans. Lead $(\mathrm{Pb})$ recorded a high concentration value after Iron $(\mathrm{Fe})$ with a mean concentration value (ppm) of $0.707 \pm 0.0008$ followed by Chromium that recorded $0.451 \pm 0.0006$ and copper $(\mathrm{Cu})$ having a value of $0.246 \pm 0.0008$. Cadmium $(\mathrm{Cd})$ had the lowest record with a mean concentration value of $0.070 \pm 0.0010$.

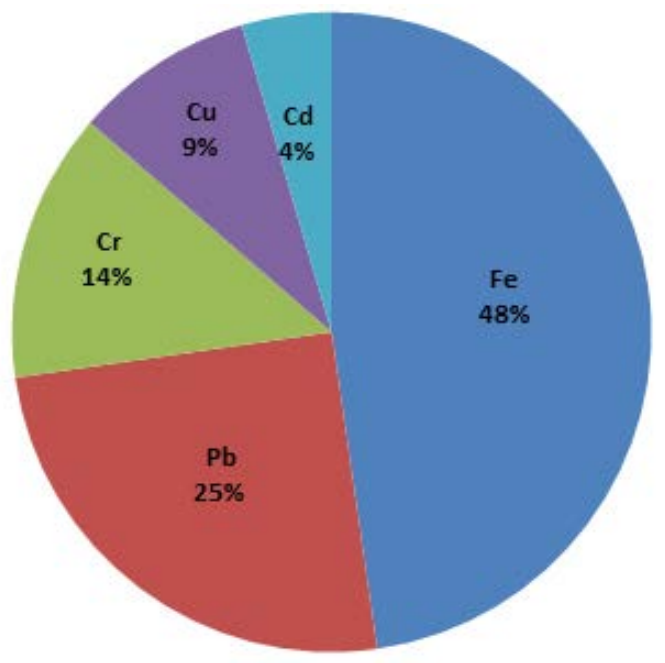

Figure 4: Percentage Concentration Values for Tombia Fish (Ictalurus Punctatus) 
Table 3: Triplicate Values of Heavy Metals Concentration (mg/kg) for Fishwithin the viscinity of Polaku(punctatusIctalurus)

\begin{tabular}{|l|l|l|l|}
\hline \multicolumn{1}{|c|}{ Heavy Metals } & \multicolumn{3}{c|}{ Concentrations (mg/kg) and their triplicate values } \\
\hline & First & Second & Third \\
\hline Copper $(\mathrm{Cu})$ & 0.002 & 0.004 & 0.001 \\
\hline Chromium $(\mathrm{Cr})$ & -0.002 & -0.001 & -0.002 \\
\hline Iron $(\mathrm{Fe})$ & 0.128 & 0.130 & 0.126 \\
\hline Lead $(\mathrm{Pb})$ & 0.003 & 0.005 & 0.004 \\
\hline Cadmium $(\mathrm{Cd})$ & -0.001 & -0.002 & -0.000 \\
\hline
\end{tabular}

Using the above expressions, the same procedure was employed in calculating for the mean, standard deviation and standard error for the Polaku Fish, and all values are expressed in milligram per kilogram (mg/kg).

Table 4: Mean Concentration values for Polaku Fish (punctatusIctalurus)

\begin{tabular}{|l|c|}
\hline Heavy Metals & Mean Concentration Values (mg/kg) \\
\hline Copper $(\mathrm{Cu})$ & $0.002 \pm 0.001$ \\
\hline Chromium $(\mathrm{Cr})$ & BDL \\
\hline Iron $(\mathrm{Fe})$ & $0.128 \pm 0.001$ \\
\hline Lead $(\mathrm{Pb})$ & $0.004 \pm 0.001$ \\
\hline Cadmium $(\mathrm{Cd})$ & BDL \\
\hline
\end{tabular}

From the above data, Iron (Fe) recorded the highest concentration with mean value of $0.128 \pm$ $0.001 \mathrm{mg} / \mathrm{kg}$ in fish within the viscinity of Polaku community, followed by lead having a mean value of $0.004 \pm 0.001 \mathrm{mg} / \mathrm{kg}$ and copper $(\mathrm{Cu})$ having the least mean concentration value of $0.002 \pm$ $0.001 \mathrm{mg} / \mathrm{kg}$. Both Chromium and Cadmium were below detection limit ie (they were not detected by the atomic absorption spectrophotometer) and that is the reason why both Chromium $(\mathrm{Cu})$ and Cadmium (Cd) are having negative (-) signs.

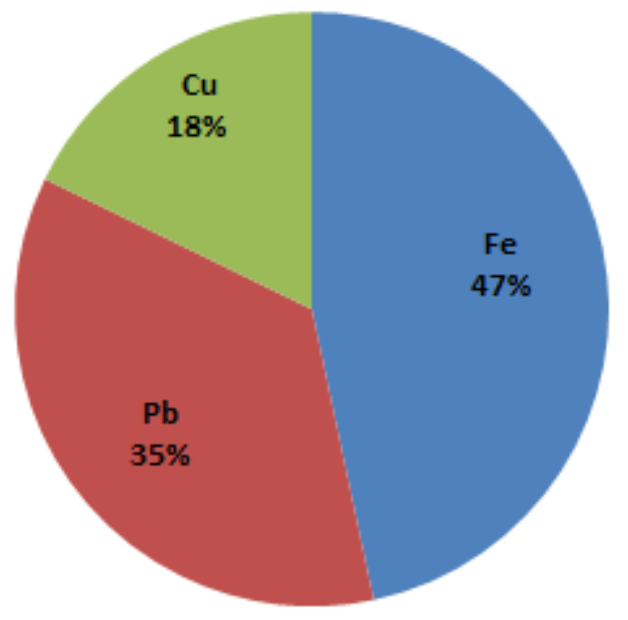

Figure 5: Percentage Concentration Values for Polaku Fish (Ictalurus Punctatus)

Note: Both Cadmium and Chromium were below detection limit (BDL) 


\subsection{Comparing the Mean Concentrations of Heavy Metals Found in Fishes within the Axis of Polaku and Tombia Community}

The variability of the heavy metals in Fish within the axis of Polaku and Tombia community was determined by comparing their mean concentrations using the table below;

\begin{tabular}{|l|c|c|l|}
\hline \multirow{2}{*}{ Heavy Metals } & \multicolumn{2}{|c|}{ Mean Concentrations (mg/kg) } & \multirow{2}{*}{ Maximum Permissible limits (mg/kg) } \\
\cline { 2 - 3 } & Tombia & Polaku & \\
\hline Iron $(\mathrm{Fe})$ & $1.910 \pm 0.001$ & $0.128 \pm 0.001$ & 0.8 (JECFA 2000), 0.5 (WHO 2003) \\
\hline Lead $(\mathrm{Pb})$ & $0.707 \pm 0.001$ & $0.004 \pm 0.001$ & $2.0($ WHO 1983, FEPA/FAO 2003) \\
\hline Chromium $(\mathrm{Cr})$ & $0.451 \pm 0.001$ & BDL & 1.0 (WHO 1983, FEPA/FAO 2003) \\
\hline Copper $(\mathrm{Cu})$ & $0.246 \pm 0.001$ & $0.002 \pm 0.001$ & 0.5 (JECFA 2000) \\
\hline Cadmium $(\mathrm{Cd})$ & $0.070 \pm 0.001$ & BDL & 0.5 (FAO 1983) 2.0 (Int\&Nat. Std 2011) \\
\hline
\end{tabular}

In comparing the order of heavy metal concentrations for the two fishes (Tombia and Polaku), the increasing order for Tombia is; $\mathrm{Fe}>\mathrm{Pb}>\mathrm{Cr}>\mathrm{Cu}>\mathrm{Cd}$, while the increasing order for Polaku fish is; $\mathrm{Fe}>\mathrm{Pb}>\mathrm{Cu}>\mathrm{Cr}>\mathrm{Cd}$

According to Joint Expert Committee for Food Additives (JECFA), the maximum permissible limits in milligram per kilogram (mg/kg) for Iron (Fe) is $0.8 \mathrm{mg} / \mathrm{kg}$ (JECFA 2000) and $0.5 \mathrm{mg} / \mathrm{kg}$ (WHO 2003) and from the data set, analysis showed that the mean concentration of Iron (Fe) in fish within the viscinity of Tombia community is more compared to Polaku community with mean value of $1.910 \pm 0.001 \mathrm{mg} / \mathrm{kg}$ and this concentration is more than the maximum permissible limit slated by JECFA. But the mean concentration value for Polaku fish is within the maximum range with a mean concentration of $0.128 \pm 0.001 \mathrm{mg} / \mathrm{kg}$ and this value is fit and recommended for human consumption.

Lead $(\mathrm{Pb})$ is classified as one of the most toxic heavy metals; excess of this heavy metal causes renal failure and liver damage in humans. The Maximum permissible limits in milligram per kilogram (mg/kg) for lead (Pb) given by the World Health Organization (WHO 1983), FEPA/FAO (2003) was $2.0 \mathrm{mg} / \mathrm{kg}$. From the data above, analysis done showed that mean concentrations of the heavy metal for both fishes (Tombia and Polaku) are within the range slated by these organizations (WHO 1983), FEPA/FAO (2003) with concentration values of $0.707 \pm 0.001$ and $0.004 \pm$ $0.001 \mathrm{mg} / \mathrm{kg}$ respectively. But in comparison, Tombia has a higher mean concentration of the heavy metal than Polaku.

Chromium (Cr) is an essential trace metal and the biologically usable form of Cr plays an essential role in glucose metabolism. But when in excess could have an undesirable lethal effect on fish and wildlife (Akan et al., 2009). Deficiency of Chromium (Cr) results in impaired growth and disturbances in glucose, lipid and protein metabolism (Calabrese et al., 1985). The maximum permissible limits given by (WHO 1983), FEPA/FAO (2003) for Chromium to be present in fish is $1.0 \mathrm{mg} / \mathrm{kg}$ and from the data set above, the mean concentration of Tombia fish is within the range given by (WHO 1983), FEPA/FAO (2003), with mean value of $0.451 \pm 0.001 \mathrm{mg} / \mathrm{kg}$. But for the case of Polaku fish, the heavy metal (Cr) was below the detection limit during analysis and that is the reason for the presence of the negative sign via the concentration value. 


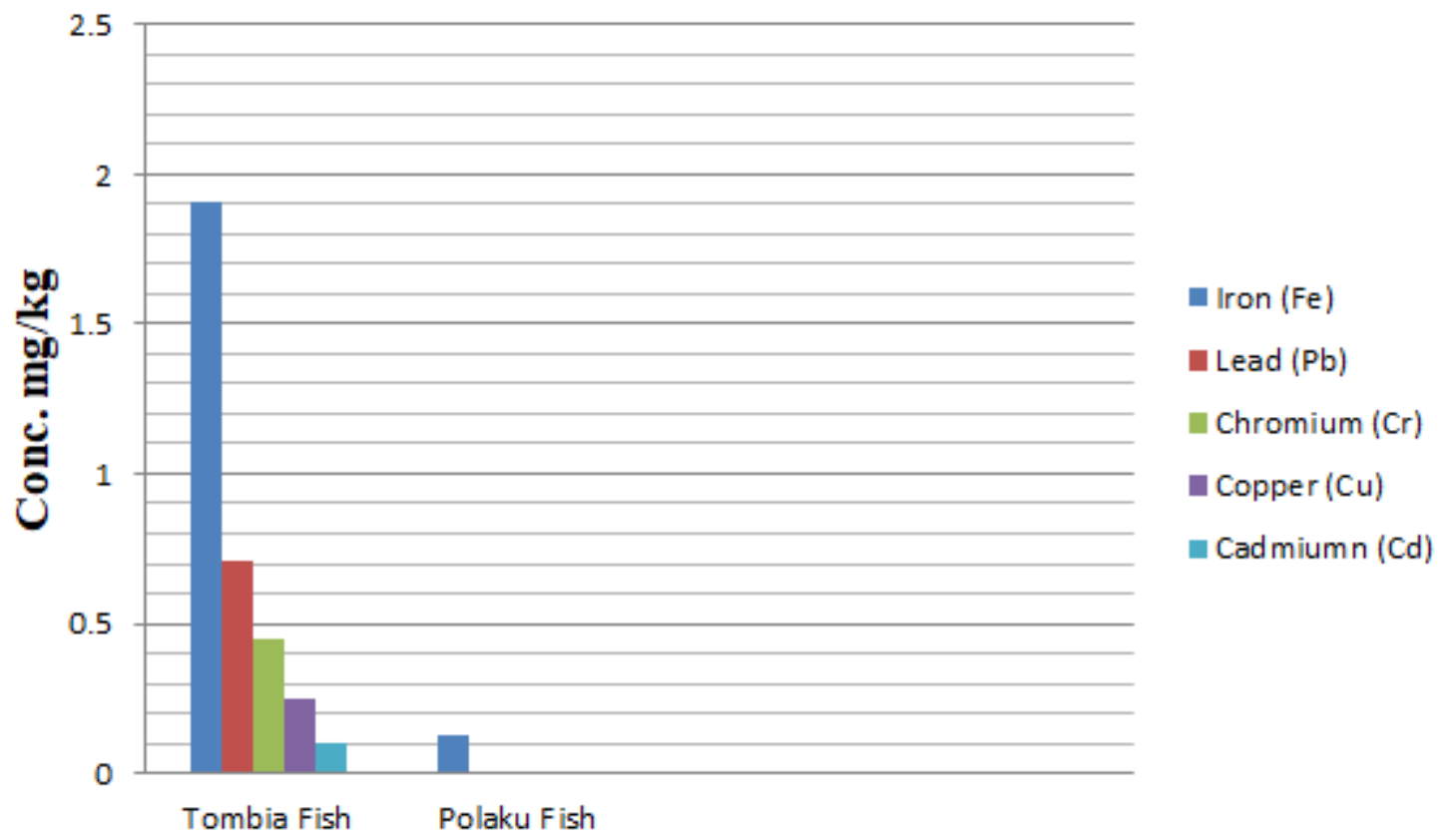

Figure 6: Fish Species (Ictalurus Punctatus)

\subsection{A Chart showing the comparison between the Fishes within the Tombia and Polaku Axis}

The maximum permissible limit slated by the Joint Expert Committee for Food Additives (JECFA) is $0.5 \mathrm{mg} / \mathrm{kg}$ (JECFA 2000).Copper $(\mathrm{Cu})$ is an essential part of several enzymes and it is necessary for the synthesis of haemoglobin. From the data set above, analysis done showed that the two fishes (Polaku and Tombia fish) are within the given range with mean concentrations of $0.246 \pm$ $0.001 \mathrm{mg} / \mathrm{kg}$ for Tombia fish and $0.002 \pm 0.001 \mathrm{mg} / \mathrm{kg}$ for Polaku fish although Tombia fish has a higer concentration than Polaku fish.

Analysis done during the course of this research showed that Cadmium was detected in small amount with a mean concentration of $0.070 \pm 0.001 \mathrm{mg} / \mathrm{kg}$ in Tombia fish while $-0.003 \pm$ $0.001 \mathrm{mg} / \mathrm{kg}$ for Polaku fish signifying that Cadmium (Cd) was below detection limit. Food and Agricultural Organizations (FAO) gave a maximum permissible limit of $0.5 \mathrm{mg} / \mathrm{kg}$ for the heavy metal (FAO 1983) whereas International and National Standard slated the maximum permissible amount of Cadmium to be present in fish organisms to be $2.0 \mathrm{mg} / \mathrm{kg}$ (Int. \& Nat. Standards 2011)

Lead $(\mathrm{Pb})$ and Cadmium $(\mathrm{Cd})$ are toxic elements which have no significant biological functions and show their carcinogenic effects on aquatic biota and humans even at low exposure. Lead $(\mathrm{Pb})$ exposure is known to cause muscular, skeletal, renal, ocular, neurological, immunological, reproductive and developmental effects. In humans, Cadmium poisoning could lead to anemia, renal damage, bone disorder and cancer of the lungs.

\section{Conclusion}

In comparing the heavy metals and the maximum permissible limits given by these organizations, it was observed that the fish within the axis of Polaku community is mostly fit for consumption compared to that of Tombia community in the sense that the analyzed heavy metals are within the slated range or in small amounts. The fish caught within the Tombia Community is also fit for consumption but excess concentration of Iron (Fe), Lead $(\mathrm{Pb})$ and Cadmium $(\mathrm{Cd})$ has to be regulated in order to fall within the range. Excess of this heavy metal $(\mathrm{Fe})$ causes life threatening 
conditions such as liver disease, heart problems, and diabetes, while lead and cadmium do not have any biological significance to the aquatic ecosystem.

\section{Recommendations}

The trace of lead $(\mathrm{Pb})$ and cadmium $(\mathrm{Cd})$ in the fish within the axis of Tombia which is not required for food consumption might be as a result of domestic activities carried out in the river and this may be due to contamination of the river by the activities of bike wash operators. Such activities must be controlled in order to maintain and avoid pollution of aquatic life.

\section{References}

[1] Akoto O, BismarkEshun F, Darko G. and Adei E. (2014): Concentrations and Health Risk Assessments of Heavy Metals in Fish from the Fosu Lagoon; Int. J.Environ. Res. 8(2):403-410

[2] Atuanya E., Nwogu N., and Akor E., (2012): Effluent qualities of government and private abattoirs and theireffects on Ikpoba River, Benin City, Edo State, Nigeria. Advances in Biological Research.6 (5):196- 201

[3] Edet O.A., Udoudo M.E., Ekam I.A., and Ngozi O.A (2014): Levels of Heavy Metals in Fish Obtained from two fishing sites in AkwaIbom State, Nigeria; African Journal of Environmental Science and Technology.8(7): 416-421

[4] Edward J. B, Idowu E. O, Oso J. A, Ibidapo O. R (2013): Determination of Heavy Metal Concentration in Fish Samples, Sediment and Water from Odo-Ayo River in Ado-Ekiti, Ekiti-State, Nigeria, International Journal of Environmental Monitoring and Analysis.1: 27-33.

[5] FAO, (1983): Compilation of legal limits for hazardoussubstances in fish and fishery products. Food and Agriculture Organization, FAO Fish Circ. 464:5-100

[6] FAO/ WHO (1984): List of maximum levels recommended for contaminants bythe joint FAO/WHO Codex Alimentarius Commission.3:1-8

[7] Farkas A., Salanki J.,and Specziar A., (2003): Age- and Size- Specific Patterns of Heavy Metals in the Organsof Freshwater Fish AbramisbramaL. Populating a Low- Contaminated Site," Water Research, 37(5):959-964

[8] Ghana A.K, Anim E.K, Ahialey G.O, Duodu M. Ackah and N.O. Bentil, (2011): Accumulation Profile of Heavy Metals in Fish Samples from Nsawam,Densu River, Chemistry Department, National Nuclear Research Institute. 1-5

[9] Goodwin T. H, Young A, Holmes M., Old G., Hewitt N., Leeks G., Packman, J. and Smith, $\quad$ B. ～(2003): “The Temporal and Spatial Variability of Sediment Transport and Yields within the Bradford Beck Catchment, West Yorkshire," Science of the Total Environment.314: 475-494.

[10] Ismaniza Ismail, Idaliza Mat Saleh 2014: Analysis of Heavy Metals in Water and Fish (tilapia sp.) samples from Tasikmutiara, puchong; The MalaysianJournal of Analytical Sciences.16(3): 346 - 352

[11] Labonne, M., Basin, S., Othman, D. and Luck, J. (2001): "Lead Isotopes in Muscelsas Tracers of Metal Sources and Water Movements in a Lagoon (Thau Basin, S. France)," Chemical Geology. 181(1): 181-191

[12] Mohammad Malakootian, MohammadSeddiqMortazavi, Abdolkarim Ahmadi $\quad$ (2016): Heavy Metals Bioaccumulation in fish of southern Iran and risk assessment of fish consumption; Environmental Health Engineering and Management Journal. 3(2): $\quad 61-68$

[13] Mozaffarian, D. \& Eric B. (2006): Fish intake, contaminants and human health: Evaluating the Risks and the Benefits; Journal of American Medical Association; 296: 1885-1900

[14] Nkpaa, K. W., Wegwu, M. O. and Essien E. B. (2013): Heavy metals concentrations in four selected seafoodfrom crude oil polluted waters of Ogoniland, Rivers State, Nigeria; $\quad$ Archives of Applied ScienceResearch. 5(4): 97104

[15] Osman, A., Wuertz, S., Mekkawy, I., Exner, H., and Kirschbaum, F. (2007): “Lead Induced Malformations in Embryos of the African Catfish Clarias Gariepinus (Burchell, 1822),” Environmental Toxicology. 22: 375-389

[16] S. Celine Hilda Mary, S. Sundaravadivel, R. Ramabai and A. Lawrence (2017), Assessment of Heavy Metals in Coastal Water and Fish Samples from Kalapet Area, Pondicherry; International Journal of Pharmaceutical Sciences and Research. 8(2): 756-762

[17] Strömgren, T. (1998): The effect of lead, cadmium, andmercury on the increase in length of five intertidal fucales: J. Exp. Marine Bio. Ecol.43 (2):107-119

[18] Olusola JO, Festus AA. (2015): Assessment of Heavy Metals in some Marine Fish Species relevant to their concentration in Water and Sediment from Coastal Waters of Ondo State, Nigeria; v5(2): Journal of Marine Science Research \&Development; 1-6 
[19] Taiwo I.O, F.I Adeosun, B.T. Adeniyi and N.A Bamidele(2016): Assessment of Heavy Metals in the Muscles and Bones of Fish and Shellfish from EpeLagoon, Nigeria; Advances in Biological Research. 10(4): 1-7, $257-263$.

[20] WHO (2000): Hazardous Chemicals in human and environmental health, Geneva.564

[21] YelizYıldırım, U. TanselŞireli, MuammerGöncüoğlu, Ali Gücükoğlu, ÖmerÇakmak 2006; Assessment of Heavy Metals (Cadmium and Lead) in Vacuum Packaged Smoked Fish Species (Mackerel, Salmosalarand Oncorhynhusmykiss) Marketed in Ankara (Turkey);E.U. Journal of Fisheries \& Aquatic Sciences;23: 353-356 